\title{
Time-course of soil microbial communities in different tillage and crop rotation systems
}

\author{
Sarahyt S. González-Figueroa ${ }^{1}$, Jorge Covarrubias-Prieto ${ }^{1}$, Cesar L. Aguirre-Mancilla ${ }^{1}$, \\ Juan C. Raya-Pérez ${ }^{1}$, Alfredo J. Gámez-Vázquez ${ }^{2}$, and Oscar A. Grageda-Cabrera ${ }^{2 *}$
}

\begin{abstract}
${ }^{1}$ Tecnológico Nacional de México, Instituto Tecnológico de Roque, Carretera Celaya-Juventino Rosas, km 8, C.P. 38110, Celaya, Guanajuato, México.

${ }^{2}$ Instituto Nacional de Investigaciones Forestales, Agrícolas y Pecuarias (INIFAP), Campo Experimental Bajío, Carretera Celaya-San Miguel de Allende, km 6,5 C.P. 38110, Celaya, Guanajuato, México. "Corresponding author (grageda.oscar@inifap.gob.mx).
\end{abstract}

Received: 26 June 2020; Accepted: 15 August 2020; doi:10.4067/S0718-58392020000400650

\begin{abstract}
The soil microbial communities involved in the biogeochemical cycles of plant nutrients are negatively affected by unfavorable agricultural practices. In three tillage systems (traditional tillage, TT; traditional tillage with residue incorporation, TTI; and conservation tillage, CT) with three crop rotations (cereal-cereal, C-C; legume-cereal, L-C; and cereal-legume, C-L) at three soil depths $(0-5,5-15$, and 15-30 $\mathrm{cm})$, the effects on the populations of bacteria, actinomycetes, and fungi over a period of six crop cycles $(3 \mathrm{yr})$ were evaluated. The tillage system, crop rotation, and depth affected the concentration of microbes in the soil. Under TT/C-C (regional control), they decreased by 7.5\%; in contrast, under CT/L-C and TTI/L-C, they increased by $144 \%$ and $76 \%$, respectively. Regardless of the tillage system, rotation with legumes, especially when the legume was cultivated in the spring-summer cycle (C-L), caused significant increases in microbial populations. At the end of $3 \mathrm{yr}$, under CT and TTI the populations of actinomycetes increased, while the fungal population remained stable and the bacterial populations fluctuated in the different crop cycles. In all treatments, the concentration of microorganisms decreased with soil depth. Local practices represent a risk to the diversity of soil microbiota, and it is imperative that farmers adopt conservation practices to achieve sustainability.
\end{abstract}

Key words: CFUs, rhizospheric microorganisms, soil degradation, Vertisol soil.

\section{INTRODUCTION}

In Mexico, there are 32.4 million ha of land for agricultural use; $44.9 \%$ shows some type of degradation, and $35 \%$ is associated with agricultural and livestock activities (SEMARNAT, 2016). Loss of fertility, pollution, and salinization are the most frequent types of soil degradation and are due to the excessive use of agrochemicals, unfavorable soil management practices, loss of vegetation cover, and decreased biological activity (Cotler et al., 2016).

Soil is an important $\mathrm{C}$ reserve that is potentially volatile, depending on the balance between photosynthesis, respiration, and stabilization. The mean $\mathrm{C}$ content in Mexican soils is $56.1 \mathrm{Mg} \mathrm{ha}^{-1}$ (Segura-Castruita et al., 2005). In addition, agricultural expansion and erosion increase $\mathrm{C}$ release, resulting in lower productivity and decreased biodiversity (Seymour and Harris, 2019). This balance, which is influenced by management practices and microbial communities, can determine the role of the soil as a reservoir or emitter of C (Trivedi et al., 2013). The metabolic diversity of these communities affects the formation of more stable recalcitrant compounds, which interact in different ways with the soil physical and chemical properties, although many indicators have been used to assess soil quality, the most sensitive indicators are biochemical attributes (Notaro et al., 2018).

To achieve sustainability, it is essential to consider the great microbial biodiversity harbored by the soil, which plays a significant role in the environmental services it provides and which has been mostly ignored in sustainable agriculture 
research. Current practices represent a risk to the vast diversity of soil microbiota, a fact that must be considered if we are to move towards truly sustainable management (FAO, 2015).

In the central region of Mexico known as El Bajío ( $c a .1 .1 \times 10^{6}$ ha), intensive agriculture, traditional tillage, cerealcereal rotation, residue burning or extraction, and poor irrigation water management have caused the loss of natural soil fertility and therefore the need to apply increasing doses of synthetic fertilizers (Grageda-Cabrera et al., 2011). Faced with this problem, it is imperative for farmers to adopt new soil and crop management practices through effective technology transfer without compromising productivity, and perhaps even increasing it (Garnett et al., 2013). For this reason, the objective of the present study was to quantify the microbial populations of bacteria, actinomycetes, and fungi under different tillage and crop rotation systems.

\section{MATERIALS AND METHODS}

A long-term experiment was conducted from June 2016 to April 2019 at Bajío Experimental Field (Campo Experimental Bajío) of the National Institute of Forest, Agricultural, and Livestock Research (Instituto Nacional de Investigaciones

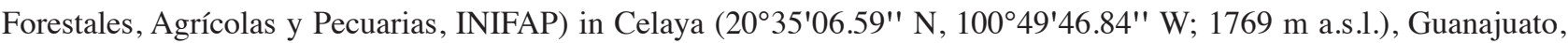
Mexico. The mean annual rainfall is $543.5 \mathrm{~mm}$ and the mean annual temperature is $18.1{ }^{\circ} \mathrm{C}$ (Table 1). The soil is classified as pelic Vertisol with a pH (1:2 water) of 7.47, organic matter content of $1.89 \%$, and a clay loam texture (FAO, 2008).

The experimental design was strip-plots subdivided over time (Gomez and Gomez, 1984) with three replicates. The vertical strip consisted of three types of tillage: traditional tillage (TT), traditional tillage with residue incorporation (TTI), and conservation tillage (LC). The horizontal strip consisted of three types of crop rotation: cereal-cereal (C-C) (regional control), legume-cereal (L-C), and cereal-legume (C-L); the regional control was TT with C-C rotation. The third strip consisted of three soil depths: 0-5, 5-15, and 15-30 cm. Each experimental unit had an approximate area of $259.2 \mathrm{~m}^{2}$. Agronomic management depended on the treatment; these practices were carried out according to the recommendations proposed by INIFAP. The experiment was performed over six crop cycles (two per year). In the spring-summer (S-S) cycles, the cereal was corn (Zea mays L.) and the legume was bean (Phaseolus vulgaris L.); in the autumn-winter (A-W) cycles, the cereal was wheat (Triticum aestivum $\mathrm{L}$.) and the legume was chickpea (Cicer arietinum $\mathrm{L}$.) The microbiological variables evaluated were the populations of bacteria, actinomycetes, and fungi. We quantified the colony forming units (CFUs) using the serial dilution and plate extension technique (Tortora et al., 2016). Soil was sampled in zig-zags at 12 points in each experimental unit at three depths: 0-5, 5-15, and 15-30 cm. Microbial populations were quantified at the beginning of the experiment and at the end of each of the six crop cycles; cycles 1,3, and 5 corresponded to springsummer (S-S), cycles 2, 4, and 6 to autumn-winter (A-W). The data were analyzed using the generalized linear model procedure and the principal component analysis procedure of SAS (SAS Institute, Cary, North Carolina, USA). Means were compared by Tukey's test when the F test was significant (HSD with $\mathrm{p} \leq 0.05$ ).

\section{RESULTS AND DISCUSSION}

The ANOVA showed highly significant differences $(\mathrm{p} \leq 0.01)$ between the main sources of variation, i.e., tillage, rotation, depth, and crop cycles, as well as between their interactions in the populations of bacteria, actinomycetes, and total microbes (Table 2). In the individual sources of variation, the highly significant differences in order of magnitude for the bacterial populations were tillage, rotation, crop cycle, and depth; for the populations of actinomycetes, tillage,

Table 1. Maximum, minimum, and average temperatures and precipitations accumulated during the experimental period from July 2016 to June 2019 (weather station INIFAP-CEBAJ).

\begin{tabular}{lcccc}
\hline Crop cycles & $\begin{array}{c}\text { Maximum } \\
\text { temperature }\end{array}$ & $\begin{array}{c}\text { Minimum } \\
\text { temperature }\end{array}$ & $\begin{array}{c}\text { Average } \\
\text { temperature }\end{array}$ & $\begin{array}{c}\text { Precipitation } \\
\text { accumulated }\end{array}$ \\
\cline { 2 - 4 } & \multicolumn{3}{c}{${ }^{\circ} \mathrm{C}$} & \\
S-S 2016 & 30.4 & 3.3 & 29.7 & $\mathrm{~mm}$ \\
A-W 2016-2017 & 34.8 & 0.2 & 31.1 & 98.0 \\
S-S 2017 & 30.7 & 0.6 & 30.2 & 367.4 \\
A-W 2017-2018 & 36.4 & -1.0 & 31.3 & 303.6 \\
S-S 2018 & 30.8 & 1.7 & 29.6 & 496.2 \\
A-W 2018-2019 & 33.7 & -5.0 & 31.2 & 99.2 \\
\hline
\end{tabular}

S-S: Spring-summer; A-W: autumn-winter. 
crop cycle, depth, and crop rotation; and for the fungal populations, depth alone. Among the interactions, the most important differences for bacteria were in TillagexDepth and TillagexCrop cycles; for actinomycetes, it was TillagexDepth and Tillage $\times$ Crop cycle; and for fungi, it was Depth $\times$ Crop cycles and Tillage $\times$ Depth.

When we analyzed the types of tillage (Table 3), bacterial populations in TTI and CT were $24.41 \%$ and $39.22 \%$ higher than in TT. The greatest bacterial development was observed in CT. The agricultural residues left on the soil surface and the nonmoving of the soil helped not disturb the dynamics of these populations. The same behavior was observed in the populations of actinomycetes, where the increases in TTI and CT were $43.69 \%$ and $118.61 \%$ with respect to TT, probably because in CT, compounds with cellulose, hemicellulose, and lignin were found in a greater proportion due to the permanence of the residues, which are used by actinomycetes, causing their predominance in surfaces with agricultural residues (Bhatti et al., 2017). The fungal populations did not differ significantly by type of tillage, but a lower amount was observed in the TT treatment, which did not incorporate residues. Similar results were obtained by AfanadorBarajas et al. (2020), who found a significant effect of agricultural management on soil properties and the content of soil microorganisms (bacteria and actinomycetes). The type of tillage influences the microbiological variables; conservation systems promote microbial populations (Bu et al., 2020; Kraut-Cohen et al., 2020; Li et al., 2020; Sun et al., 2020).

Table 2. Mean squares, degrees of freedom and statistical significance of ANOVA for microbial populations at different tillage systems and crop rotation through six growing seasons at three soil depths.

\begin{tabular}{|c|c|c|c|c|c|}
\hline \multirow[b]{2}{*}{ Source of variation } & \multirow[b]{2}{*}{$\mathrm{df}$} & \multicolumn{4}{|c|}{ Mean square } \\
\hline & & Bacteria & Actinomycetes & Fungi & Total \\
\hline Replication & 2 & $0.8083 \mathrm{~ns}$ & $0.5826 \mathrm{~ns}$ & $0.0003 \mathrm{~ns}$ & $2.4814 \mathrm{~ns}$ \\
\hline Tillage (T) & 2 & $46.742 * *$ & $161.767 * *$ & $0.0009 \mathrm{~ns}$ & $373.926^{* *}$ \\
\hline Error a & 4 & 0.0822 & 0.5087 & 0.0009 & 0.6904 \\
\hline Crop rotation $(\mathrm{R})$ & 2 & $13.856^{* *}$ & $20.091 * *$ & $0.0017 \mathrm{~ns}$ & $54.702 * *$ \\
\hline Error b & 4 & 0.1883 & 0.1142 & 0.0008 & 0.2650 \\
\hline $\mathrm{T} \times \mathrm{R}$ & 4 & $10.425 * *$ & $13.729 * *$ & $0.0015 \mathrm{~ns}$ & $48.276^{* *}$ \\
\hline Error c & 18 & 0.0665 & 0.1217 & 0.0004 & 0.3843 \\
\hline Soil depths (D) & 2 & $2.799 * *$ & $61.654 * *$ & $0.0725^{* *}$ & $68.771 * *$ \\
\hline $\mathrm{T} \times \mathrm{D}$ & 4 & $12.430 * *$ & $35.721 * *$ & $0.0167 * *$ & $30.987 * *$ \\
\hline $\mathrm{R} \times \mathrm{D}$ & 4 & $10.171 * *$ & $7.872 * *$ & $0.0127 * *$ & $27.424 * *$ \\
\hline $\mathrm{T} \times \mathrm{R} \times \mathrm{D}$ & 8 & $6.543 * *$ & $9.865^{* *}$ & $0.0245^{* *}$ & $16.207 * *$ \\
\hline Error d & 36 & 0.181 & 0.248 & 0.0028 & 0.416 \\
\hline Crop cycles (C) & 6 & $8.259 * *$ & $71.796 * *$ & $0.0014 \mathrm{~ns}$ & $67.714 * *$ \\
\hline $\mathrm{T} \times \mathrm{C}$ & 12 & $12.310 * *$ & $28.299 * *$ & $0.0022 \mathrm{~ns}$ & $25.055^{* *} *$ \\
\hline $\mathrm{R} \times \mathrm{C}$ & 12 & $10.855^{* *}$ & $11.602 * *$ & $0.0009 \mathrm{~ns}$ & $5.340 * *$ \\
\hline $\mathrm{D} \times \mathrm{C}$ & 12 & $7.508 * *$ & $13.424 * *$ & $0.0285^{* *}$ & $27.918 * *$ \\
\hline $\mathrm{T} \times \mathrm{R} \times \mathrm{C}$ & 24 & $6.302 * *$ & $6.542 * *$ & $0.0013 \mathrm{~ns}$ & $3.960 * *$ \\
\hline $\mathrm{T} \times \mathrm{D} \times \mathrm{C}$ & 24 & $8.972 * *$ & $9.237 * *$ & $0.0142 * *$ & $17.756^{* *}$ \\
\hline $\mathrm{R} \times \mathrm{D} \times \mathrm{C}$ & 24 & $10.597 * *$ & $8.855^{* *}$ & $0.0100 * *$ & $31.872 * *$ \\
\hline $\mathrm{T} \times \mathrm{R} \times \mathrm{D} \times \mathrm{C}$ & 48 & $12.425 * *$ & $7.291 * *$ & $0.0150 * *$ & $24.157 * *$ \\
\hline Error & 324 & 0.1790 & 0.233 & 0.0017 & 0.496 \\
\hline $\mathrm{CV}, \%$ & & 18.776 & 17.615 & 27.330 & 13.860 \\
\hline
\end{tabular}

**Significant at the 0.01 probability level; ns: nonsignificant; df: degrees of freedom; CV: coefficient of variation.

Table 3. Microbial populations in soil under different tillage systems over a period of six crop cycles.

\begin{tabular}{|c|c|c|c|c|}
\hline \multirow[b]{2}{*}{ Tillage } & \multirow[b]{2}{*}{ Bacteria } & \multicolumn{3}{|c|}{ Microbial populations } \\
\hline & & Actinomycetes & Fungi & Total \\
\hline & & $-\mathrm{CF}$ & & \\
\hline TT & $5.2638 \mathrm{c}$ & $5.4998 \mathrm{c}$ & $0.454362 \mathrm{a}$ & $11.2180 \mathrm{c}$ \\
\hline TTI & $6.7801 \mathrm{~b}$ & $7.6572 \mathrm{~b}$ & $0.461016 \mathrm{a}$ & $14.8984 \mathrm{~b}$ \\
\hline CT & $8.2475 \mathrm{a}$ & $11.0078 \mathrm{a}$ & $0.468142 \mathrm{a}$ & $19.6353 \mathrm{a}$ \\
\hline HSD & 0.4349 & 0.5206 & 0.0260 & 0.8331 \\
\hline
\end{tabular}

Means followed by different letter in each column are significantly different according to the HSD test $(\mathrm{p} \leq 0.05)$.

TT: Traditional tillage; TTI: traditional tillage with residue incorporation; CT: conservation tillage; CFUs: colony forming units. 
Lower soil disturbance preserves microhabitats, creating a better environment for microbial growth (Zuber and Villamil, 2016; Li et al., 2018). In addition, the degree of disturbance also influences the microbial utilization rate of $\mathrm{C}$ and of other elements, which causes significant differences in microbial diversity and catabolic diversity (Wang et al., 2020). The type of tillage influences the physical properties of the soil (Hubbard et al., 2013), and these properties correlate with bacterial communities.

Table 4 shows the results of the microbial populations evaluated in the different crop rotations. The L-C rotation increased bacterial populations, while the $\mathrm{C}$ - $\mathrm{L}$ rotation increased the populations of actinomycetes. In contrast, the C-C rotation had the lowest amounts of bacteria and actinomycetes. Fungal populations were significantly similar between the rotations. The total populations increased when there was rotation with legumes. This pattern was also observed by Song et al. (2007), who, through various evaluation cycles, cultivated cereal with legume and concluded that intercropping promotes the development of bacterial populations. Each plant species produces different amounts and compositions of exudates, which promotes microorganism diversity and abundance (Merbach et al., 1999). The C-L and L-C rotations are favorable for soil management since they increase the development of microbial populations, possibly due to the types of organisms that develop in each type of crop. However, it is difficult for local farmers to consider this aspect since the economic gains from the sale of crops are greater with the C-C rotation.

In the evaluation of microbial populations at different depths, the number of microorganisms decreased as the depth in the soil profile increased (Table 5). However, the bacterial populations showed the same concentration in the 0-5 and $5-15 \mathrm{~cm}$ strata, while fungal populations were significantly equal between $5-15$, and $15-30 \mathrm{~cm}$. This pattern coincides with studies in which microbial biomass often decreases with soil depth (Hartmann et al., 2009; Zhang et al., 2019). Eilers et al. (2012), when analyzing soil microbial communities at different depths, found significant differences between profiles separated by $10 \mathrm{~cm}$, and the same was observed in the present study. In addition, those authors highlighted that changes in environmental conditions with soil depth influenced microbial communities, with the most pronounced effects in the first $25 \mathrm{~cm}$. The communities of microorganisms in the soil live predominantly aerobically; that is, they need oxygen for their metabolism, and oxygen decreases as the depth increases (Ball et al., 1990).

In the analysis of the microbial populations over the six crop cycles (Table 6), there were variations between cycles, which could have been due to the climatic conditions in each of them. In addition, each type of microorganism showed a different behavior. Considering the mean of all treatments, fungi were the most stable against these changes, and the general trend was an increase in microbial population over the course of the six crop cycles.

Table 4. Microbial populations in soil under different crop rotations over a period of six crop cycles.

\begin{tabular}{llllc}
\hline & & \multicolumn{3}{c}{ Microbial populations } \\
\cline { 3 - 5 } Crop rotation & Bacteria & Actinomycetes & Fungi & Total \\
\cline { 2 - 5 } & & & & \\
C-C & $5.9439 \mathrm{c}$ & $7.0669 \mathrm{c}$ & $0.466931 \mathrm{a}$ & $13.3896 \mathrm{~b}$ \\
L-C & $7.5683 \mathrm{a}$ & $8.0751 \mathrm{~b}$ & $0.450569 \mathrm{a}$ & $16.0939 \mathrm{a}$ \\
C-L & $6.7792 \mathrm{~b}$ & $9.0229 \mathrm{a}$ & $0.466020 \mathrm{a}$ & $16.2681 \mathrm{a}$ \\
HSD & 0.4349 & 0.5206 & 0.0260 & 0.3707 \\
\hline
\end{tabular}

Means followed by different letter in each column are significantly different according to the HSD test $(\mathrm{p} \leq 0.05)$.

C-C: Cereal-cereal rotation; L-C: legume-cereal rotation; C-L: cereal-legume rotation; CFUs: colony forming units.

Table 5. Microbial populations in soil under different soil depths over a period of six crop cycles.

\begin{tabular}{lllll}
\hline \multirow{2}{*}{$\begin{array}{l}\text { Soil depths } \\
(\mathrm{cm})\end{array}$} & & \multicolumn{3}{c}{ Microbial populations } \\
\cline { 3 - 5 } & Bacteria & Actinomycetes & Fungi & Total \\
\cline { 2 - 5 } $0-5$ & $2.3657 \mathrm{a}$ & $3.1709 \mathrm{a}$ & $0.1748 \mathrm{a}$ & $5.6641 \mathrm{a}$ \\
$5-15$ & $2.2735 \mathrm{a}$ & $2.8280 \mathrm{~b}$ & $0.1501 \mathrm{~b}$ & $5.1264 \mathrm{~b}$ \\
$15-30$ & $2.1245 \mathrm{~b}$ & $2.0558 \mathrm{c}$ & $0.1361 \mathrm{~b}$ & $4.4599 \mathrm{c}$ \\
HSD & 0.1391 & 0.1595 & 0.0172 & 0.2065 \\
\hline
\end{tabular}

Means followed by different letter in each column are significantly different according to the HSD test $(\mathrm{p} \leq 0.05)$.

CFUs: Colony forming units. 
Table 6. Microbial populations in each of six crop cycles.

\begin{tabular}{llccc}
\hline & & \multicolumn{3}{c}{ Microbial populations } \\
\cline { 3 - 5 } Crop cycle & Bacteria & Actinomycetes & Fungi & Total \\
\cline { 2 - 5 } IS & $6.6366 \mathrm{bc}$ & $4.0971 \mathrm{e}$ & $0.4523 \mathrm{a}$ & $11.1861 \mathrm{~d}$ \\
$1^{*}$ & $7.2142 \mathrm{ab}$ & $5.4178 \mathrm{~d}$ & $0.4541 \mathrm{a}$ & $12.8805 \mathrm{c}$ \\
2 & $7.2786 \mathrm{ab}$ & $7.2510 \mathrm{c}$ & $0.4853 \mathrm{a}$ & $15.0150 \mathrm{~b}$ \\
3 & $7.4019 \mathrm{ab}$ & $7.3846 \mathrm{c}$ & $0.4666 \mathrm{a}$ & $15.2531 \mathrm{~b}$ \\
4 & $4.8973 \mathrm{~d}$ & $9.7990 \mathrm{~b}$ & $0.4484 \mathrm{a}$ & $15.1448 \mathrm{~b}$ \\
5 & $6.2328 \mathrm{c}$ & $11.9605 \mathrm{a}$ & $0.4557 \mathrm{a}$ & $18.6491 \mathrm{a}$ \\
6 & $7.6852 \mathrm{a}$ & $10.4746 \mathrm{~b}$ & $0.4655 \mathrm{a}$ & $18.6253 \mathrm{a}$ \\
HSD & 0.8175 & 0.9786 & 0.0488 & 1.5659 \\
\hline
\end{tabular}

Means followed by different letter in each column are significantly different according to the HSD test $(\mathrm{p} \leq 0.05)$.

*Sampling done after harvest.

CFUs: Colony forming units; IS: initial sampling; Cycles 1, 3, and 5 corresponded to springsummer cycles 2,4 , and 6 to autumn-winter.

In the principal component analysis of the TillagexRotation interaction (Table 7), the most important variables were expressed in principal component 1 (PC1): bacteria, actinomycetes, and total microbes. PC2 contained only fungi, continuous cropping could increase the relative abundance of some fungi (Bai et al., 2018). Both principal components together explained $97.1 \%$ of the total variation.

Figure 1 shows the results of the principal component analysis of the TillagexRotation interaction, where three groups were formed. The first was characterized by the abundance of bacteria and actinomycetes, highlighting the CT/C-L and $\mathrm{CT} / \mathrm{L}-\mathrm{C}$ interactions, which shared in common the type of tillage and rotations that included legumes. At the opposite extreme, the group with the lowest population of bacteria and actinomycetes was that treated with TT regardless of the rotation used. In the central part of the graph, there is a group formed by TTI with its respective rotations and $\mathrm{CT} / \mathrm{C}-\mathrm{C}$, which presented intermediate amounts of bacteria and actinomycetes. Within each group, differences were observed with respect to the fungal population; the group formed by CT/C-L and CT/L-C shows a greater amount of these microorganisms, and the results may be due to the type of residue, the time of application, and the $\mathrm{C}: \mathrm{N}$ ratio (Martínez and Leyva, 2014). In CT/C-L, wheat straw, with a C:N ratio of 87, was added in the S-S cycle, and bean straw (C:N 17) was added in the A-W cycle. In CT/L-C, chickpea straw (C:N 21) was added in the S-S and corn straw (C:N 65) in the A-W. It is likely that the amount of added $\mathrm{C}$ promoted an increase in fungal populations, since these maintain a $\mathrm{C}: \mathrm{N}$ ratio of 10:1, greater than that of bacteria (5:1) or actinomycetes (6:1) (Troeh and Thompson, 2005).

In the principal component analysis of the TillagexDepth interaction, the most important variables were expressed in PC1: bacteria, fungi, and total microbes. PC2 was only actinomycetes. Both principal components together explained $92.1 \%$ of the total variation generated (Table 8 ).

Table 7. Characteristic vectors of the principal components for the microbial populations evaluated in the Tillage systems $\times$ Crop rotation interaction over a period of six crop cycles in the $0-30 \mathrm{~cm}$ soil profile.

\begin{tabular}{llc}
\hline \multirow{2}{*}{$\begin{array}{l}\text { Variable } \\
\text { (microbial populations) }\end{array}$} & \multicolumn{2}{c}{ Characteristic vectors } \\
\cline { 2 - 3 } & \multicolumn{1}{c}{$\mathrm{PC} 1$} & $\mathrm{PC} 2$ \\
\hline Bacteria & 0.544043 & -0.236284 \\
Actinomycetes & 0.561397 & -0.061493 \\
Fungi & 0.5613 & 0.96043 \\
Total & 0.571475 & -0.134021 \\
Characteristic value & 3.008068 & 0.8791832 \\
Explained variance, \% & 75.2 & 21.9 \\
\hline
\end{tabular}

PC1: Principal component 1; PC2: Principal component 2. 
Figure 1. Principal components analysis of microbial populations evaluated in soil under different tillage systems and crop rotation over period of six crop cycles in the $0-30 \mathrm{~cm}$ soil profile.
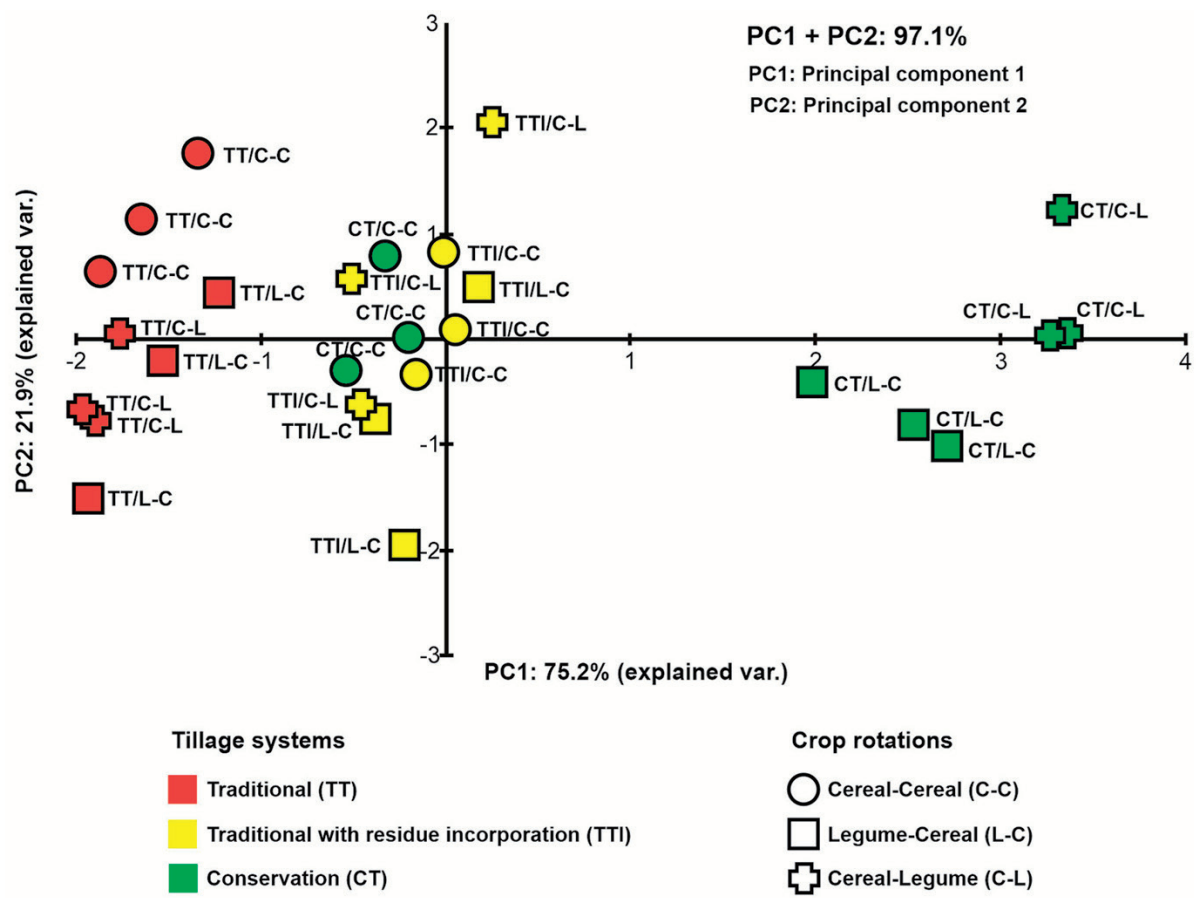

Table 8. Characteristic vectors of the principal components for the microbial populations evaluated in the Tillage systems $\times$ Soil depths $(0-5,5-15$, and $15-30 \mathrm{~cm})$ interactions over a period of six crop cycles.

\begin{tabular}{lcc}
\hline \multirow{2}{*}{$\begin{array}{l}\text { Variable } \\
\text { (microbial populations) }\end{array}$} & \multicolumn{2}{c}{ Characteristic vectors } \\
\cline { 2 - 3 } & $\mathrm{PC} 1$ & $\mathrm{PC} 2$ \\
\hline Bacteria & 0.441481 & -0.609447 \\
Actinomycetes & 0.351374 & 0.770668 \\
Fungi & 0.569648 & 0.133271 \\
Total & 0.597605 & -0.129937 \\
Characteristic value & 2.71381084 & 0.96927093 \\
Explained variance, \% & 67.8 & 24.2 \\
\hline
\end{tabular}

PC1: Principal component 1; PC2: Principal component 2.

The results of the principal component analysis of the treatments evaluated in the TillagexDepth interaction are shown in Figure 2. In PC1, the largest populations of fungi and bacteria were present under CT/0-5 cm and the lowest in TT/15$30 \mathrm{~cm}$. Bu et al. (2020) observed increases in bacterial populations when there were crop residues because in CT, soil movement was zero and the cover with crop residues was left as mulch on the surface. $\mathrm{C}$ and $\mathrm{N}$, as well as moisture, were more abundant on the soil surface, which results in an increase in the levels of microbial activity (Zuber and Villamil, 2016; Somenahally et al., 2018). The central part of the graph shows the TTI treatment with all the profiles. In turn, the population of actinomycetes remained constant in and similar between TT and TTI, but there were variations in the CT, where actinomycetes decreased as the depth increased (CT/15-30). The results agree with those reported by Hartmann et al. (2009), who noted that soil profiles are influenced by the environment and by multiple edaphic factors that change with depth. One of the most pronounced changes throughout the profiles was the almost exponential decrease in microbial biomass, a pattern that paralleled the decrease in $\mathrm{C}$, an abundant surface component in the cover residues.

Table 9 shows the principal component analysis of the TillagexCrop cycle interaction. The most important variables for principal component 1 (PC1) were fungi, bacteria, and total microbes, and for PC2, it was actinomycetes alone. Both principal components together explained $80.6 \%$ of the total variation generated. 
Figure 2. Principal components analysis of microbial populations evaluated in soil under different tillage systems and three soil depths over period of six crop cycles.

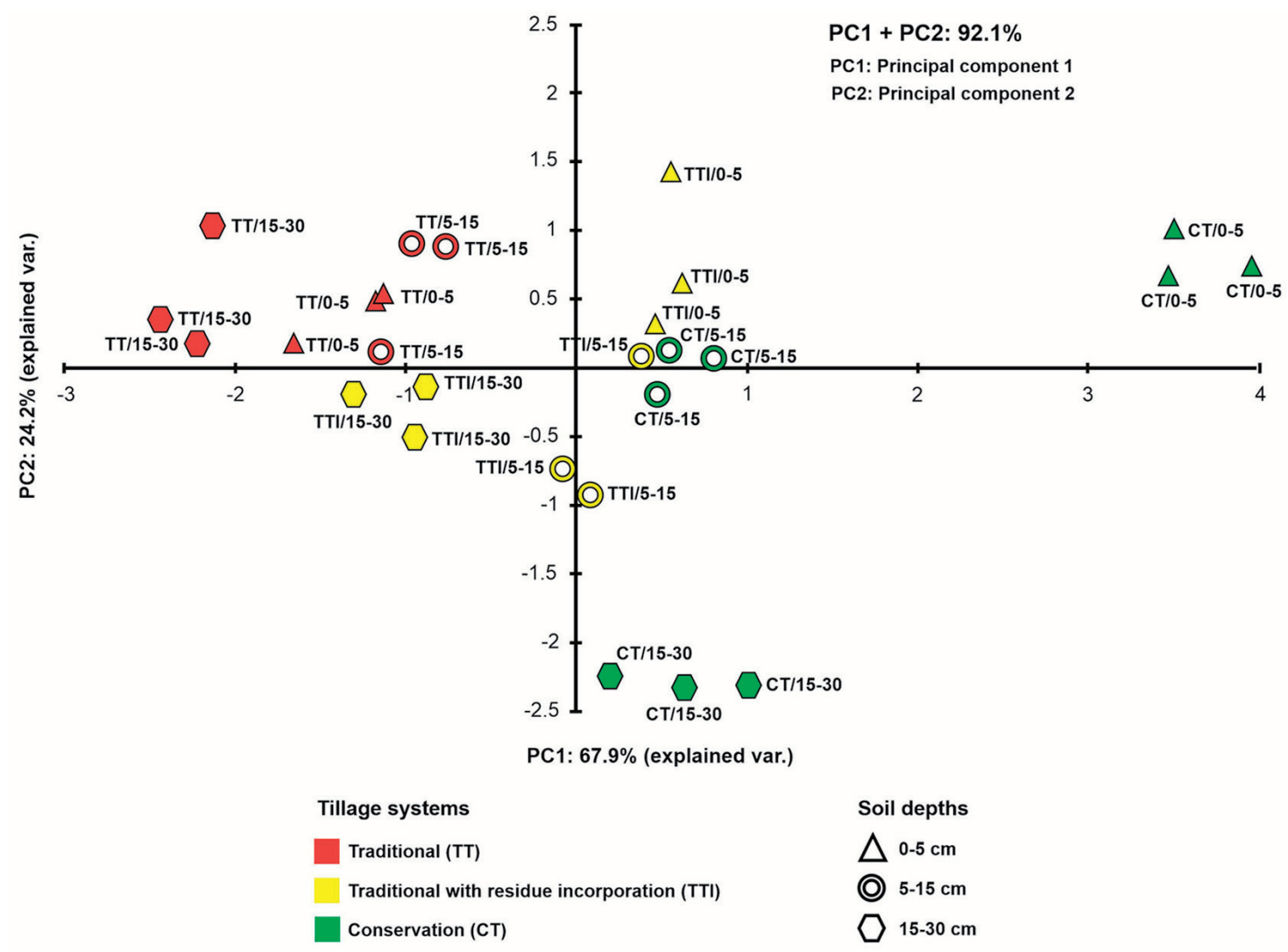

Table 9. Characteristic vectors of the principal components for the microbial populations evaluated in the Tillage systems $\times$ Crop cycle interaction in the $0-30 \mathrm{~cm}$ soil profile.

\begin{tabular}{lcc}
\hline \multirow{2}{*}{$\begin{array}{l}\text { Variable } \\
\text { (microbial populations) }\end{array}$} & \multicolumn{2}{c}{ Characteristic vectors } \\
\cline { 2 - 3 } & $\mathrm{PC} 1$ & $\mathrm{PC} 2$ \\
\hline Bacteria & 0.321243 & -0.694601 \\
Actinomycetes & 0.228549 & 0.673349 \\
Fungi & 0.617264 & 0.229724 \\
Total & 0.680848 & -0.10657 \\
Characteristic value & 2.1057415 & 1.1199067 \\
Explained variance, \% & 52.6 & 28.0 \\
\hline
\end{tabular}

PC1: Principal component 1; PC2: Principal component 2.

Figure 3 shows the behavior of the microbial populations in the different tillage systems over time. In CT, the fungal and bacterial populations increased, especially in cycles $5(\mathrm{~S}-\mathrm{S})$ and 6 (A-W). In turn, differences were found in the actinomycete populations, probably related to the temperature conditions and rainfall distributions of each cycle. Martín and Rivera (2000) noted that a stable cover helps increase the organic matter content and improves the soil structure, protecting it from the impact of rainfall and solar radiation, favoring the thriving of soil microbiota. The tillage system that allowed the next-greatest concentration of microorganisms was TTI, and the maximum values were obtained in TTI/C5 and TTI/C6. In turn, under TT, the fungal and bacterial populations stayed low, while the actinomycetes increased in the A-W cycles (C2, C4, and C6). The type of tillage influences the transformation of nutrients (Cheng et al., 2017). Residue mantles or incorporation of residues can influence the stability of the soil microclimate (Blanco-Canqui and Ruis, 2018), the distribution and decomposition of raw organic matter, and the organic matter content (Li et al., 2018; Somenahally et al., 2018). 
Figure 3. Principal components analysis of microbial populations evaluated in soil under different tillage systems and six crop cycles in the $0-30 \mathrm{~cm}$ soil profile.

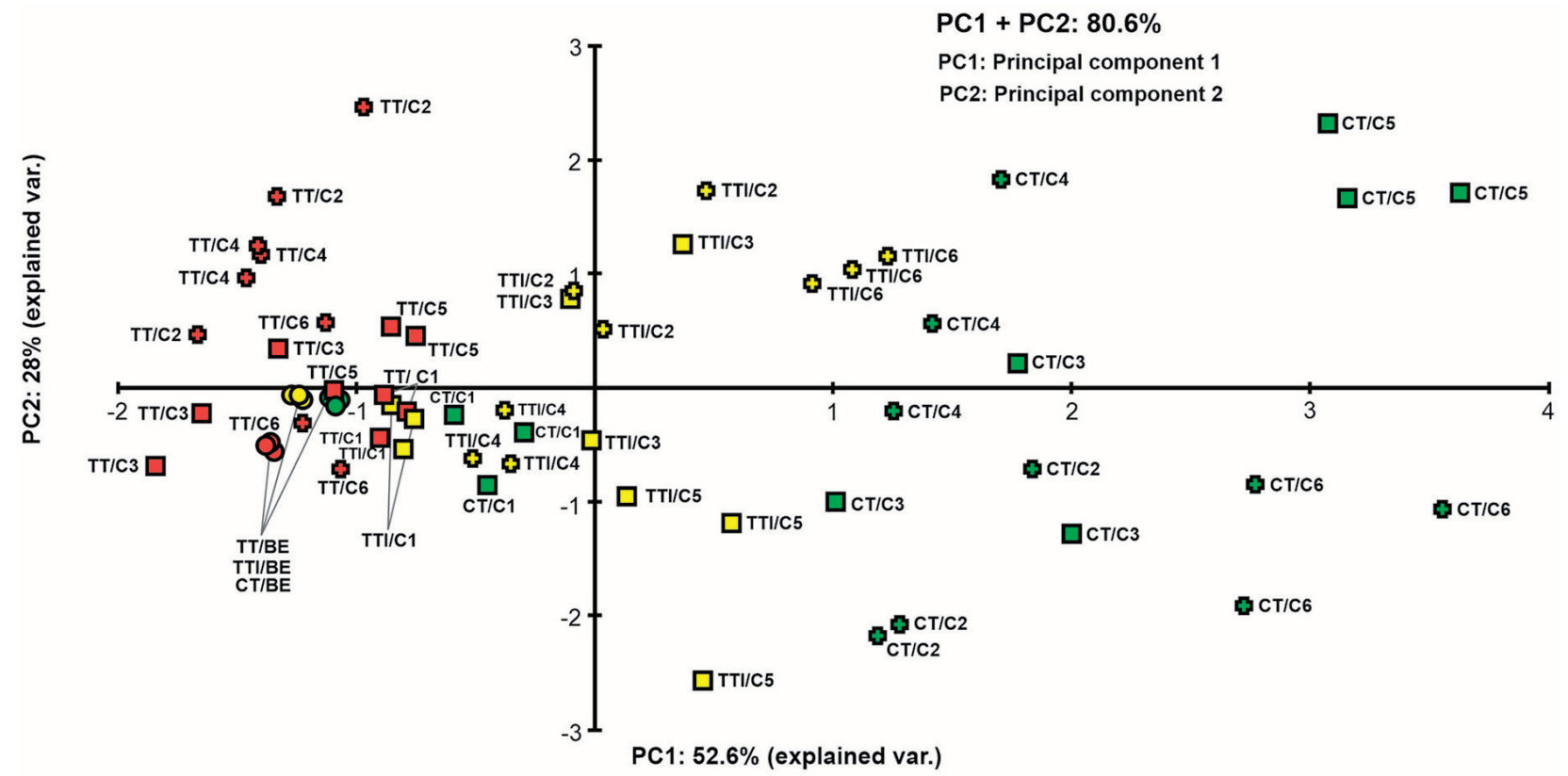

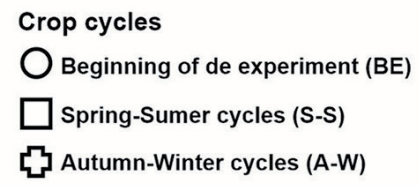

Crop cycles

illage systems

Traditional (TT)

Traditional with residue incorporation (TTI)

Conservation (CT)
PC2: Principal component 2 
Figure 4. Changes in soil microbial communities in soil under different tillage systems and crop rotation over period of six crop cycles in the $0-30 \mathrm{~cm}$ soil profile.

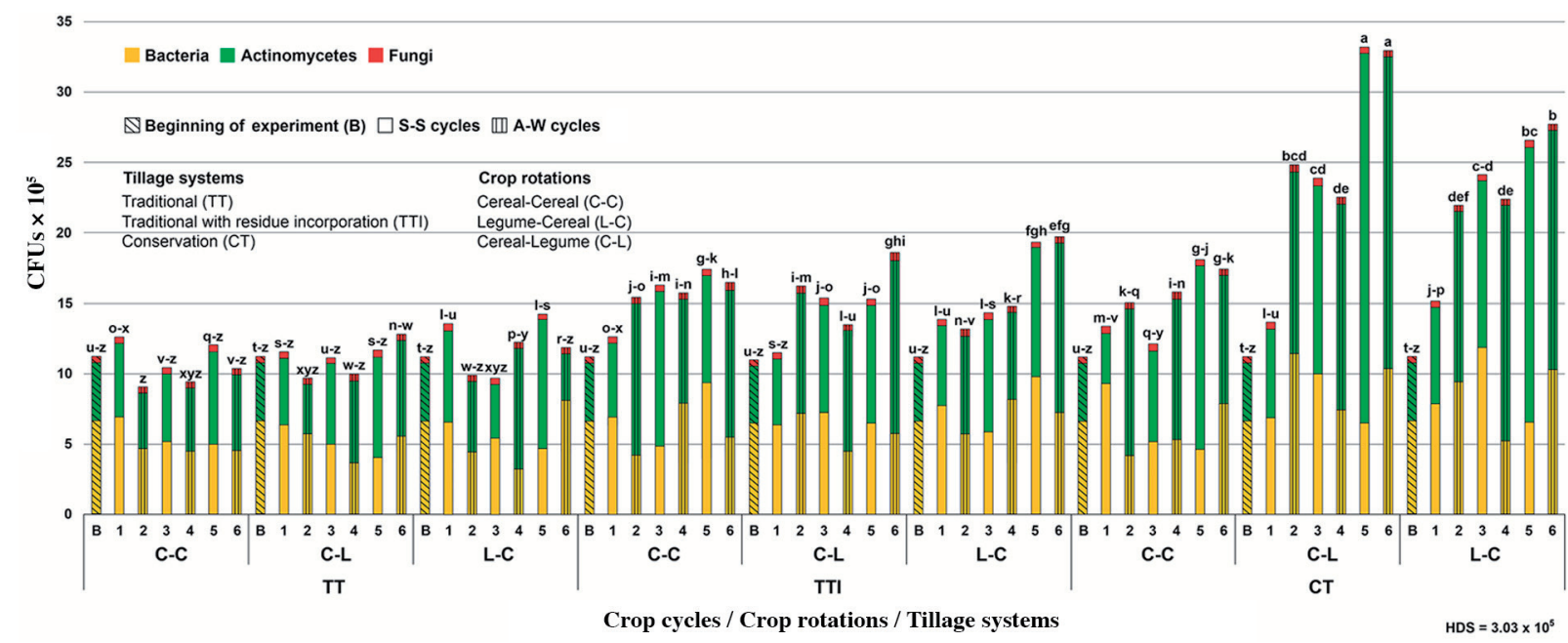

Means followed by different letter in the bars are significantly different according to the HSD test $(\mathrm{p} \leq 0.05)$. S-S: Spring-summer; A-W: autumn-winter; CFUs: colony forming units.

\section{CONCLUSIONS}

The tillage system and crop rotation directly affected the patterns of microbial populations in the soil. In the traditional tillage/cereal-cereal (TT/C-C) treatment (regional control), the microbial populations decreased, and over time, the microbiological degradation of the soil may become irreparable. When comparing the types of tillage, conservation tillage (CT) showed the greatest increases in microbial populations. Likewise, when there was cereal-legume (C-L) or legume-cereal (L-C) rotation, traditional tillage with residue incorporation (TTI) contributed to significant increases in microbial populations, equaling those under CT/C-C and CT/C-L. Rotations with different species had different effects, and C-L contributed to increasing the populations in all three types of tillage. Regardless of the treatment, fungal populations remained stable throughout the experiment, and those of actinomycetes increased considerably under TTI and CT. Regarding the depth of the soil profile, in all treatments the concentration of microorganisms decreased with depth. The study of microbial behaviors in the soil is essential to identifying agronomic strategies to prevent or correct their degradation.

\section{REFERENCES}

Afanador-Barajas, L.N., Coca-Peña, D.A., Vargas-Giraldo, A.P., Bautista-Murcia, M.F., Mendoza-Hernández, A., y VallejoQuintero, V.E. 2020. Evaluación de la calidad de suelos en agroecosistemas de Colombia a través de la selección de un conjunto mínimo de datos. Colombia Forestal 23(1):35-50. https://doi.org/10.14483/2256201X.14856.

Bai, L., Sun, H., Zhang, X., and Cai, B. 2018. Next-generation sequencing of root fungal communities in continuous cropping soybean. Chilean Journal of Agricultural Research 78:528-538. doi:10.4067/S0718-58392018000400528.

Ball, A.S., Godden, B., Helvenstein, P., Penninckx, M.J., and McCarthy, A.J. 1990. Lignocarbohydrate solubilization from straw by actinomycetes. Applied and Environmental Microbiology 56:3017-3022.

Bhatti, A.A., Haq, S., and Bhat, R.A. 2017. Actinomycetes benefaction role in soil and plant health. Microbial Pathogenesis 111:458-467. https://doi.org/10.1016/j.micpath.2017.09.036.

Blanco-Canqui, H., and Ruis, S.J., 2018. No-tillage and soil physical environment. Geoderma 326:164-200. https://doi.org/10.1016/j.geoderma.2018.03.011.

Bu, R., Ren, T., Lei, M., Liu, B., Li, X., Cong, R., et al. 2020. Tillage and straw-returning practices effect on soil dissolved organic matter, aggregate fraction and bacteria community under rice-rice-rapeseed rotation system. Agriculture, Ecosystems and Environment 287:106681 . https://doi.org/10.1016/j.agee.2019.106681. 
Cheng, Y., Wang, J., Wang, J., Chang, S.X., and Wang, S. 2017. The quality and quantity of exogenous organic carbon input control microbial $\mathrm{NO}_{3}$ immobilization: a metaanalysis. Soil Biology and Biochemistry 115:357-363. https://doi.org/10.1016/j.soilbio.2017.09.006.

Cotler, H., Martínez, M., y Etchevers, J.D. 2016. Carbono orgánico en suelos agrícolas de México: Investigación y políticas públicas. Terra Latinoamericana 34(1):125-138.

Eilers, K.G., Debenport, S., Anderson, S., and Fierer, N. 2012. Digging deeper to find unique microbial communities: the strong effect of depth on the structure of bacterial and archaeal communities in soil. Soil Biology and Biochemistry 50:58-65. https://doi.org/10.1016/j.soilbio.2012.03.011.

FAO. 2008. Base referencial mundial del recurso suelo. Informes sobre recursos mundiales de suelos. Reporte $\mathrm{N}^{\circ} 103$. FAO, Roma, Italia.

FAO. 2015. Soils and biodiversity: Soils host a quarter of our planet's biodiversity. FAO, Rome, Italy. Available at http://www.fao.org/3/a-i4551e.pdf.

Garnett, T., Appleby, M.C., Balmford, A., Bateman, I.J., Benton, T.G., Bloomer, P., et al. 2013. Sustainable intensification in agriculture: premises and policies. Science 341(6141):33-34. doi:10.1126/science.1234485.

Gomez, K.A., and Gomez, A.A. 1984. Statistical procedures for agricultural research. An international rice research institute book. Wiley-Interscience, New York, USA.

Grageda-Cabrera, O.A., Vera-Núñez, J.A., Aguilar-Acuña, J.L., Macías-Rodríguez, L., Aguado-Santacruz, G.A., and PeñaCabriales, J.J. 2011. Fertilizer dynamics in different tillage and crop rotation systems in a Vertisol in Central Mexico. Nutrient Cycling in Agroecosystems 89(1):125-134. https://doi.org/10.1007/s10705-010-9382-4.

Hartmann, M., Lee, S., Hallam, S.J., and Mohn, W.W. 2009. Bacterial, archaeal and eukaryal community structures throughout soil horizons of harvested and naturally disturbed forest stands. Environmental Microbiology 11(12):30453062. https://doi.org/10.1111/j.1462-2920.2009.02008.x.

Hubbard, R.K., Strickland, T.C., and Phatak, S. 2013. Effects of cover crop systems on soil physical properties and carbon/nitrogen relationships in the coastal plain of southeastern USA. Soil and Tillage Research 126:276-283. https://doi.org/10.1016/j.still.2012.07.009.

Kraut-Cohen, J., Zolti, A., Shaltiel-Harpaz, L., Argaman, E., Rabinovich, R., Green, S.J., et al. 2020. Effects of tillage practices on soil microbiome and agricultural parameters. Science of the Total Environment 705:135791. https://doi. org/10.1016/j.scitotenv.2019.135791.

Li, Y., Chang, S.X., Tian, L.H., and Zhang, Q.P. 2018. Conservation agriculture practices increase soil microbial biomass carbon and nitrogen in agricultural soils: a global metaanalysis. Soil Biology and Biochemistry 121:50-58. https://doi.org/10.1016/j.soilbio.2018.02.024.

Li, Y., Zhang, Q., Cai, Y., Yang, Q., and Chang, S.X. 2020. Minimum tillage and residue retention increase soil microbial population size and diversity: Implications for conservation tillage. Science of the Total Environment 137164. https://doi.org/10.1016/j.scitotenv.2020.137164.

Martín, G.M., y Rivera, R. 2000. Mineralización de dos especies promisorias de abonos verdes en suelo Ferralítico Rojo (Ferralsol) mediante el método de incubación aeróbica. Cultivos Tropicales 21(2):73-78.

Martínez,A., y Leyva, A. 2014. La biomasa de los cultivos en el ecosistema. Sus beneficios agroecológicos. Cultivos Tropicales 35(1):11-20.

Merbach, W., Mirus, E., Knof, G., Remus, R., Ruppel, S., Russow, R., et al. 1999. Release of carbon and nitrogen compounds by plant roots and their possible ecological importance. Journal of Plant Nutrition and Soil Science 162:373-383.

Notaro, K.A., de Medeiros, E.V., Duda, G.P., Moreira, K.A., de Barros, J.A., dos Santos, U.J., et al. 2018. Enzymatic activity, microbial biomass, and organic carbon of Entisols from Brazilian tropical dry forest and annual and perennial crops. Chilean Journal of Agricultural Research 78:68-77. doi:10.4067/S0718-58392018000100068.

Segura-Castruita, M.A., Sánchez-Guzmán, P., Ortiz-Solorio, C.A., y Gutiérrez-Castorena, M.C. 2005. Carbono orgánico de los suelos de México. Terra Latinoamericana 23(1):21-28.

SEMARNAT. 2016. Informe de la Situación del Medio Ambiente en México. Compendio de Estadísticas Ambientales. Indicadores clave, de desempeño ambiental y de crecimiento verde. Edición 2015. Secretaría del Medio Ambiente y Recursos Naturales (SEMARNAT), Ciudad de México, México.

Seymour,F., and Harris, N.L. 2019. Reducing tropical deforestation. Science 365:756-757. https://doi.org/10.1126/science.aax8546.

Somenahally, A., DuPont, J.I., Brady, J., McLawrence, J., Northup, B., and Gowda, P. 2018. Microbial communities in soil profile are more responsive to legacy effects of wheat-cover crop rotations than tillage systems. Soil Biology and Biochemistry 123:126-135. https://doi.org/10.1016/j.soilbio.2018.04.025.

Song, Y.N., Zhang, F.S., Marschner, P., Fan, F.L., Gao, H.M., Bao, X.G., et al. 2007. Effect of intercropping on crop yield and chemical and microbiological properties in rhizosphere of wheat (Triticum aestivum L.), maize (Zea mays L.), and faba bean (Vicia faba L.) Biology and Fertility of Soils 43(5):565-574. https://doi.org/10.1007/s00374-006-0139-9.

Sun, B., Chen, X., Zhang, X., Liang, A., Whalen, J.K., and McLaughlin, N.B. 2020. Greater fungal and bacterial biomass in soil large macropores under no-tillage than mouldboard ploughing. European Journal of Soil Biology 97:103155. https://doi.org/10.1016/j.ejsobi.2020.103155. 
Tortora, G.J., Funke, B.R., and Case, C.L. (eds.) 2016. Microbiology: An introduction. 12 $2^{\text {th }}$ ed. Pearson, London, UK.

Trivedi,P., Anderson, I.C., and Singh, B.K.2013. Microbial modulators of soil carbon storage: integrating genomic and metabolic knowledge for global prediction. Trends in Microbiology 21(12):641-651. https://doi.org/10.1016/j.tim.2013.09.005.

Troeh, F.R., and Thompson, L.M. 2005. Soils and soil fertility. $6^{\text {th }}$ ed. Blackwell, New York, USA.

Wang,Z.,Li, T.,Li, Y.,Zhao,D., Han, J.,Liu, Y., et al. 2020. Relationship between the microbial community and catabolic diversity in response to conservation tillage. Soil and Tillage Research 196:104431. https://doi.org/10.1016/j.still.2019.104431.

Zhang, G., Huang, J., Jia, M., Huang, W., Sui, X., Wang, Z., et al. 2019. Effect of different grazing intensities on bacterial community composition and diversity in rhizosphere and non-rhizosphere soils in desert steppe of China. Chilean Journal of Agricultural Research 79:531-546. doi:10.4067/S0718-58392019000400531.

Zuber, S.M., and Villamil, M.B. 2016. Meta-analysis approach to assess effect of tillage on microbial biomass and enzyme activities. Soil Biology and Biochemistry 97:176-187. https://doi.org/10.1016/j.soilbio.2016.03.01. 